IRELAND AND THE PROBLEM OF INFORMATION 


\section{IRELAND AND THE}

PROBLEM OF

INFORMATI O N

IRISH WRITING,

RADIO,

LATE MODERNIST

COMMUNICATION

\section{DAMIEN KEANE}


Permission to quote Louis MacNeice's poem

"The Unoccupied Zone" has been granted by the Estate of Louis MacNeice and David Higham Associates.

Permission to cite the Princeton Listening Center Records has been granted by the Princeton University Library.

Thanks to the deputy keeper of the records at the Public Record Office of Northern Ireland for help with the records of the Northern Ireland Cabinet. An earlier version of part of chapter I appeared in

"De Valera, Du Bois, and the Ethiopian Crisis," Foilsiú 5, no. I (2006): I-II. An earlier version of part of chapter 4 appeared in "Francis Stuart to America, 9 June 1940," Dublin Review I4 (Spring 2004): 53-56.

Library of Congress Cataloging-in-Publication Data Keane, Damien, 1973- , author.

Ireland and the problem of information : Irish writing, radio, late modernist communication / Damien Keane.

pages $\quad \mathrm{cm}$-(Refiguring modernism)

Summary: "A series of studies examining literary modernism in Ireland. Explores how cultural work assumed new meaning amid the strategic imperatives of the mid-twentieth century, and demonstrates how the late modernist field became today's information age"-Provided by publisher.

Includes bibliographical references and index. ISBN 978-0-27I-064I2-3 (cloth : alk. paper)

I. Modernism (Literature)-Ireland-

History-2oth century.

2. English literature-Irish authors2oth century-History and criticism.

3. Radio broadcasting-Ireland-History—2oth century. 4. World War, 1939-I945-Radio broadcasting and the war. I. Title.

II. Series: Refiguring modernism.

$$
\begin{gathered}
\text { PR8755.K427 } 2014 \\
820.9 \text { 'II2O94I5-dc23 } \\
\text { 20I40I5839 }
\end{gathered}
$$

Copyright (C) 2014 The Pennsylvania State University All rights reserved

Printed in the United States of America

Published by The Pennsylvania State University Press, University Park, PA I6802-I003

The Pennsylvania State University Press is a member of the Association of American University Presses.

It is the policy of The Pennsylvania State University Press to use acid-free paper. Publications on uncoated stock satisfy the minimum requirements of American National Standard for Information Sciences-Permanence of Paper for Printed Library Material, ANSI Z39.48-I992.

This book is printed on paper that contains $30 \%$ post-consumer waste. 
FOR my mother 
